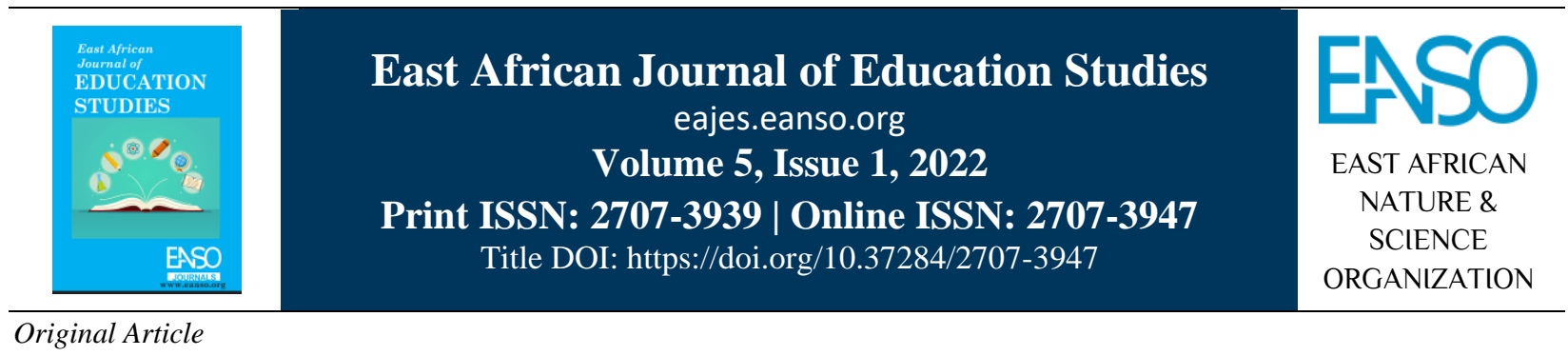

\title{
Doing Action Research: The Experience of Teachers in Seychelles.
}

\author{
Dr. Raymond Ndubisi Anyanwu, $\mathrm{PhD}^{1^{*}}$ \& Rosianna Jules ${ }^{2}$ \\ ${ }^{1}$ University of Seychelles, Anse Royale, Seychelles. \\ ${ }^{2}$ Seychelles Institute of Teacher Education (SITE), Mont Fleuri, Seychelles. \\ * Author for Correspondence ORCID: https://orcid.org/0000-0001-5050-7879; Email: raymond.anyanwu@ unisey.ac.sc.
}

Article DOI: https://doi.org/10.37284/eajes.5.1.528

\section{Date Published: ABSTRACT}

28 January 2022 Action research is regarded as a dynamic strategy to galvanise teachers to determine what works best for them and their pupils. Teachers' experience in action research Keywords: has been investigated in some developing countries without involving any of the

Doing Action

Research,

Experience,

Successes,

Concerns,

Issues,

Seychelles. small island states in the Indian Ocean. Hence, this study explored the experience of teachers from Seychelles regarding action research focusing on their understanding of the nature, meaning, and purpose of action research; the benefits they gained from doing action research; the difficulties and the challenges they encountered while conducting action research, including their background characteristics. Its aim was to identify their successes, concerns, and issues. Participants were 33 primary school teachers enrolled in the two-year Advanced Diploma programme at the Seychelles Institute of Education during the 2019/2020 academic year. One of their assessment tasks required them to identify a difficulty that their pupils encounter and conduct action research on it with a view to finding a solution. Data collected using a selfreporting questionnaire designed by the investigators was analysed using both descriptive and interpretive techniques. Results indicated that the participants had a mixed experience of successes, concerns, and issues.

\section{APA CITATION}

Anyanwu, R. N., \& Jules, R. (2022). Doing Action Research: The Experience of Teachers in Seychelles. East African Journal of Education Studies, 5(1), 14-25. https://doi.org/10.37284/eajes.5.1.528.

\section{CHICAGO CITATION}

Anyanwu, Raymond Ndubisi, and Rosianna Jules. 2022. "Doing Action Research: The Experience of Teachers in Seychelles". East African Journal of Education Studies 5 (1), 14-25. https://doi.org/10.37284/eajes.5.1.528.

\section{HARVARD CITATION}

Anyanwu, R. N. \& Jules, R. (2022) “Doing Action Research: The Experience of Teachers in Seychelles", East African Journal of Education Studies, 5(1), pp. 14-25. doi: 10.37284/eajes.5.1.528.

\section{IEEE CITATION}

R. N. Anyanwu, \& R. Jules, "Doing Action Research: The Experience of Teachers in Seychelles”, EAJES, vol. 5, no. 1, pp. 1425, Jan. 2022.

14 | This work is licensed under a Creative Commons Attribution 4.0 International License. 


\section{MLA CITATION}

Anyanwu, Raymond Ndubisi, and Rosianna Jules. "Doing Action Research: The Experience of Teachers in Seychelles". East African Journal of Education Studies, Vol. 5, no. 1, Jan. 2022, pp. 14-25, doi:10.37284/eajes.5.1.528.

\section{INTRODUCTION}

Teachers used to expect outsiders to offer solutions to the problems they and their pupils encountered in the classroom. As quality and accountability become the cornerstone of the education system in developing countries including Seychelles, schools and policymakers are under increased pressure to seek more dynamic strategies to galvanise teachers to find out what works best in their classroom (Srinivasacharlu, 2019; Darling-Hammond, Hyler \& Gardner, 2017). One of the important strategies to motivate teachers to become researchers in their domain is action research (Khan et al., 2019; Cabaroglu, 2014). Consequently, most teacher education institutions have incorporated action research into their curriculum with the aim to nurture trainees' competencies in research methodology (Hine, 2013).

As teacher research becomes a dynamic teacher professional development strategy, understanding teachers' experience regarding action research becomes germane so that appropriate support can be provided to improve teaching practice. Experience is the lived, first-hand acquaintance with, and account of, the entire span of our minds and actions, with the emphasis not on the context of the action but on the immediate and embodied, and thus inextricably personal, nature of the content of the action (Depraz, Varela \& Vermersch, 2003). This definition implies that a single action or event can be experienced in different ways by different individuals, and can be expressed through self-talk, self-writing, or self-narration (Daher et al., 2017; Roth \& Jornet, 2014).

Some researchers have examined teachers' experience regarding action research using samples from the developing countries, for example; the Philipines (Ulla, 2018; Morales, Abulon \& Soriano et al., 2016); Malaysia (Norasmah \& Chiah, 2016); Iran (Leila \& Morteza, 2015); Kosovo (Vula \& Saqipi 2015), and Kazakhstan (Nagibova, 2016). These studies employed mostly the inductive method which seeks to establish limited generalisations about the distribution of, and patterns of association amongst, observed or measured characteristics of individuals (Malhotra, 2017). This is with the exception of Vula and Saqipi (2015) study that involved in-service teachers; the rest involved full-serving ones. Albeit they identified their motives for and challenges/obstacles in doing action research, none explored teachers' understanding of the meaning, nature and, purpose of action research; and the benefits, difficulties, and challenges in doing action research in a single study. Notably, none of the previous studies aimed to identify their successes, concerns, and issues, and none was conducted with samples from a small island state in the Indian Ocean. In an effort to close these gaps, the present study investigates the experience of teachers in Seychelles regarding action research with the aim to identify their successes, concerns, and issues, so that training institutions will take them into consideration in future programme delivery. The study's theoretical framework is presented in the next section.

\section{LITERATURE}

Definitions of research abound in the literature. In layman language, research refers to a search for understanding (UNESCO Institute of Statistics, 2021). For the purpose of this study, research is a careful and systematic way of solving problems and gaining new knowledge (Asenahabi, 2019). Characteristically, research is demanding. It draws on all one's confidence, courage, resilience, and doggedness; hence Millar (2016:10) describes it as the most intimidating of all academic tasks. Carson (2007) cautions against solving a problem without first researching into it, adding that the first step in solving a problem is to become aware of it and then seek to define what it is or what it requires for its solution (p. 11). Some people have difficulty when defining research because they do not understand that scientific research usually starts with having a problem and willingness to solve a problem (Bahçekapili et al., 2013).

There are assorted definitions of action research in the literature, but for the purpose of this study, action research is a type of inquiry carried out by practitioners with a view to improve their 
professional practice and understand it better (Khasinah, 2013, p. 108). It differs from traditional or scientific research in that the researcher is not removed from what is being studied but rather is a part of it (Martin-Kniep, 2000, p. 89). For those in education, action research is concerned with practitioners examining a school situation to understand and improve the quality of the educative process (Hine, 2013, p. 152). Given that teachers and pupils encounter diverse difficulties and challenges in the classroom, it is crucial that classroom teachers know how to conduct action research because they are responsible for their students learning process (Rubio, 2010:43) and are in a better position than anyone else to find out what works best in their own classroom so that they can improve student learning (Mettetal, 2001, p. 1). For teachers to make a positive difference in their pupils' learning they must learn how to work with and learn from one another (Orgoványi-Gajdos, 2016; Shanks, 2016).

Several benefits in conducting action research have been identified in the literature. According to Petit (2010, p. 820), action research provides an alternative approach to bringing about changes in knowledge, policy, and practice. It also provides teachers with the technical skills and specialised knowledge required to be transformative within their professional domain (Hine \& Lavery, 2014). Furthermore, action research provides practitioners with the opportunity to examine their interactions and relationships in social settings seeking opportunities for improvement (Riel, 2019: Vula \& Saqipi, 2015), enhances student achievement (Vula \& Saqipi, 2015) and offers opportunities for job promotion/salary increment (Ulla, 2018).

Teachers encounter numerous difficulties and challenges when doing action research. Some research studies (see Ulla, 2018; Morales et al., 2016) found that teachers had a positive view about action research and experienced a moderate level of difficulty when conducting it; however, they required professional development on statistical analysis, data organisation, literature search and report writing. Nagibova (2016) identified a myriad of academic challenges encountered by teachers when conducting action research, including lack of theoretical knowledge about action research, insufficient practice in action research, lack of motivation, lack of ICT skills, language skills, reflection, and research skills, and time management. Norasmah and Chiah (2016) identified workload and time constraints, lack of action research knowledge and skills, and limited support as some of the challenges faced by teachers when doing action research. Other researchers (Ulla, 2018) found that teachers experienced a lack of financial support from the school, a lack of training on how to conduct action research, and a lack of research resources and a loaded timetable when doing action research. Leila and Morteza (2015) categorised the obstacles teachers face when doing action research as 'individual obstacles' comprising educational, attitudinal, and skill obstacles; 'organisational and skill obstacles' comprising motivational and structural obstacles; and 'environmental obstacles' mostly lack resources and facilities. These observations were incorporated into the present study's instrument for data collection and to corroborate the results. The next section presents the methods of the study.

\section{MATERIALS AND METHODS}

\section{The Research Setting}

This research study was conducted in 2020 at the Seychelles Institute of Teacher Education (SITE), situated in Mahe, the main island and most populated. Other habitable islands are Praslin and La Digue. There are 24 public primary schools with about 800 teachers in the country. SITE is one of the ten professional centres in the country and the only one offering pre-service and in-service programmes in early childhood, primary and secondary education at certificate, diploma, and advanced diploma levels. As of January 2018, SITE began training supply teachers as well as teachers who possess the Lower Diploma (Diploma 1) via the Blended Learning Mode also known as the BLM. Thirty-eight teachers holding the Diploma in Education were enrolled in the two-year Advanced Diploma (AD) programme, with at least one trainee from each state primary school sponsored by the Ministry of Education. The trainees are released from duty two days each week (Thursday and Friday) for training at SITE and three days (Monday, Tuesday, and Wednesday) for teaching at their schools. One of their signature courses is 'Introduction to Educational Research, offered for 
the first time following some revisions to the course content. The main assessment task for the course is an action research project to be completed by each student under the supervision of their lecturer (Tertiary Education Seychelles, 2020; Ministry of Education, 2019; Economic Commission for Africa, 2018).

\section{Instrument}

A questionnaire titled 'Action Research Experience Questionnaire' (AREQ) designed by the investigators was used to collect data from the participants by offering them the opportunity to express in writing their experience regarding action research. It consists of six sections, A to F. The variables have ordered categories so that it will be possible to locate where a respondent belongs, see the overall pattern of responses, and make generalisations regarding their successes, concerns, and issues. Section A collects background information of participants: gender, age range, number of years in teaching, present teaching cycle, the difficulty mostly encountered by learners in the Cycle, experience in action research, the place of research at the school, and the school leadership. Findings from this section will be used to support analysis and discussion of results.

Section B collected data on the meaning and purpose of action research. Questions are as follows: i) What do you understand by 'Research'? ii) Why is it important to research a problem before attempting a solution? iii) What is 'Action Research? iv) Why is it necessary that a classroom teacher should know how to conduct action research? The participants were also asked to justify their answers. Section C consists of 10 items on the benefits of doing action research. Response categories are 'Strongly Agree, Agree, Disagree, and Strongly Disagree. The participants were asked to indicate the category that represents their opinion for each item by inserting a tick.

Section D consists of 15 items on the difficulties in doing action research with levels of difficulty as High, Medium, and Low. The participants were asked to indicate the level they encountered for each item by inserting a tick. Section E consists of 10 items on the challenges in doing action research. There are three levels of challenges: High, Medium, and Low, and the participants were asked to indicate the level for each item as they experienced it. Section $F$ requires the participants to express in writing any other experience they had while doing their project.

\section{Population and Sampling}

The AD cohort was chosen for this study purposively because they are the first cohort of teachers enrolled at SITE to conduct action research as their assessment task. Since 38 teachers were registered for the course, the investigators decided to employ the No-Rule sampling, which allows every member of the group to participate in the survey, so long as the person is willing. This sampling design allows for collecting rich data which is crucial in qualitative research.

\section{Procedure}

Given that the participants were employees of the Ministry of Education, the investigators sought approval from the Principal Secretary in the Ministry of Education to allow them to complete the survey. Their role in the study was also explained to them before the questionnaire was distributed to them by their course lecturer while they were submitting their action research report. They were allowed two days to complete and return it. Out of the 38 questionnaires distributed, thirty-three were returned.

\section{Data Analysis Techniques}

Returned questionnaires were first coded ADE-01 to 33, conforming to the number of participants before being captured in MS Excel for analysis. Numerical data were analysed with the descriptive technique to condense the data into a simpler summary showing frequencies and percentages. The interpretive content analysis technique was employed to analyse textual data with a view to extracting meaning from the answers provided by the participants. Results and findings are presented in the next section. 
East African Journal of Education Studies, Volume 5, Issue 1, 2022

Article DOI: https://doi.org/10.37284/eajes.5.1.528

\section{RESULTS}

Table 1: Characteristics of participants

\begin{tabular}{|c|c|c|c|}
\hline Variable & Variable categories & $\mathbf{N}$ & $\%$ \\
\hline \multirow{2}{*}{ Gender } & Female & 31 & 93.9 \\
\hline & Male & 2 & 6.1 \\
\hline \multirow{2}{*}{ Age } & More than 30 & 33 & 100 \\
\hline & Less than 30 & 0 & 0 \\
\hline \multirow{2}{*}{ Teaching Experience (in yrs) } & More than 10 & 33 & 100 \\
\hline & Less than 10 & 0 & 0 \\
\hline \multirow{5}{*}{ Teaching grade } & Creche & 9 & 27.3 \\
\hline & Cycle 1 (P1-P2) & 8 & 24.2 \\
\hline & Cycle 2 (P3-P4) & 1 & 3 \\
\hline & Cycle 3 (P5-P6) & 13 & 39.4 \\
\hline & Management & 2 & 6.1 \\
\hline \multirow{7}{*}{$\begin{array}{l}\text { The difficulty encountered by } \\
\text { majority of learners }\end{array}$} & Comprehension & 8 & 24.2 \\
\hline & Concentration & 3 & 9.1 \\
\hline & Listening & 1 & 3 \\
\hline & Low motivation & 3 & 9.1 \\
\hline & Reading & 14 & 42.4 \\
\hline & Writing & 3 & 9.1 \\
\hline & Non-Response & 1 & 3 \\
\hline \multirow{2}{*}{ Experience in conducting AR } & Yes & 1 & 3 \\
\hline & No & 32 & 97 \\
\hline \multirow{3}{*}{$\begin{array}{l}\text { The place for AR in your } \\
\text { school }\end{array}$} & Yes & 2 & 6.1 \\
\hline & No & 27 & 81.8 \\
\hline & Non-Response & 4 & 12.1 \\
\hline \multirow{3}{*}{ Type of school leadership } & Committed to innovation & 21 & 63.6 \\
\hline & Not committed to innovation & 8 & 24.2 \\
\hline & Non-Response & 4 & 12.1 \\
\hline
\end{tabular}

Table 1 shows that the participants of this study are demographically heterogeneous, except for age and teaching experience.

Table 2: The pattern of responses pertaining to the meaning, nature and purpose of action research

\begin{tabular}{|c|c|c|c|c|}
\hline Items & Benchmark & $\begin{array}{l}\text { Response } \\
\text { category }\end{array}$ & Common phrases used & $\mathbf{N}(\%)$ \\
\hline \multirow[t]{3}{*}{$\begin{array}{l}\text { What do } \\
\text { understand } \\
\text { research? }\end{array}$} & \multirow[t]{3}{*}{$\begin{array}{l}\text { Asenahabi } \\
(2019: 77)\end{array}$} & $\begin{array}{l}\text { Correct } \\
\text { Response }\end{array}$ & $\begin{array}{l}\text { Investigation into a problem; taking a deeper } \\
\text { look into a problem, gaining more information } \\
\text { about it; going in-depth into something through } \\
\text { observation, collecting data, coming to a } \\
\text { conclusion; investigation/study of phenomena } \\
\text { to establish facts, reach a new conclusion. }\end{array}$ & $27(82)$ \\
\hline & & $\begin{array}{l}\text { Incorrect } \\
\text { Response }\end{array}$ & $\begin{array}{l}\text { Participants examine their own educational } \\
\text { practices; systematically and carefully; } \\
\text { investigation into a problem in your school }\end{array}$ & $6(18)$ \\
\hline & & NR & - & 0 \\
\hline
\end{tabular}

18 This work is licensed under a Creative Commons Attribution 4.0 International License. 


\begin{tabular}{|c|c|c|c|c|}
\hline Items & Benchmark & $\begin{array}{l}\text { Response } \\
\text { category }\end{array}$ & Common phrases used & $\mathbf{N}(\%)$ \\
\hline \multirow{3}{*}{$\begin{array}{l}\text { Why is it } \\
\text { important to } \\
\text { research a } \\
\text { problem before } \\
\text { attempting a } \\
\text { solution to it? }\end{array}$} & \multirow[t]{3}{*}{$\begin{array}{l}\text { Carson } \\
(2007: 11)\end{array}$} & $\begin{array}{l}\text { Correct } \\
\text { Response }\end{array}$ & $\begin{array}{l}\text { Understand the nature of a problem in order to } \\
\text { find an appropriate solution to it; understand the } \\
\text { root cause of the problem. }\end{array}$ & $25(76)$ \\
\hline & & $\begin{array}{l}\text { Incorrect } \\
\text { Response }\end{array}$ & $\begin{array}{l}\text { To build knowledge and facilitate learning; } \\
\text { understand various issues in teaching'; identify } \\
\text { learners' difficulties before diagnosing } \\
\text { remediation }\end{array}$ & $4(12)$ \\
\hline & & NR & & $4(12)$ \\
\hline \multirow[t]{3}{*}{$\begin{array}{l}\text { What is Action } \\
\text { Research? }\end{array}$} & \multirow[t]{3}{*}{$\begin{array}{l}\text { Khasinah } \\
(2013: 108)\end{array}$} & $\begin{array}{l}\text { Correct } \\
\text { Response }\end{array}$ & $\begin{array}{l}\text { An investigation by a person experiencing a } \\
\text { problem in order to find a solution/ } \\
\text { improvement; identify a problem affecting your } \\
\text { school/class and find the solution, improve the } \\
\text { situation; investigate a problem taking place in } \\
\text { your class/workplace, come up with a solution; } \\
\text { a systematic investigation by teachers in an } \\
\text { attempt to solve problems and improve } \\
\text { professional practices, to improve their students } \\
\text { learn; acting upon a problem identified in your } \\
\text { class/workplace. }\end{array}$ & $27(82)$ \\
\hline & & $\begin{array}{l}\text { Incorrect } \\
\text { Response }\end{array}$ & $\begin{array}{l}\text { Research that is done by someone involved in } \\
\text { the problem to improve the method/approach of } \\
\text { those involved; identifying a problem and } \\
\text { implementing intervention on it; a process of } \\
\text { collecting information, analysing data, and } \\
\text { sharing information. }\end{array}$ & $6(18)$ \\
\hline & & NR & - & 0 \\
\hline \multirow[t]{3}{*}{$\begin{array}{l}\text { Is it necessary } \\
\text { that a classroom } \\
\text { teacher should } \\
\text { know how to } \\
\text { conduct action } \\
\text { research? Give a } \\
\text { reason } \\
\text { for your answer. }\end{array}$} & \multirow[t]{3}{*}{$\begin{array}{l}\text { Mettetal, } \\
(2001: 1)\end{array}$} & Yes & $\begin{array}{l}\text { Justification: } \\
\text { Remedy a problem experienced by students in } \\
\text { his/her class; bring about improvement in } \\
\text { teaching and in students' performance; solve a } \\
\text { problem or find solutions in our schools; find a } \\
\text { solution to difficulties faced by learners; helps } \\
\text { teachers to know when/how to intervene to help } \\
\text { the learners overcome their difficulties }\end{array}$ & $33(100)$ \\
\hline & & No & - & 0 \\
\hline & & NR & - & 0 \\
\hline
\end{tabular}

Table 2 shows that the majority of the participants understood the meaning, nature, and purpose of action research.

Table 3: The pattern of responses on the benefits of doing action research

\begin{tabular}{|c|c|c|c|c|c|}
\hline Items & SA & $\mathbf{A}$ & D & SD & NR \\
\hline $\begin{array}{l}\text { Doing action research has increased my awareness } \\
\text { of the needs of pupils in my class. }\end{array}$ & $\begin{array}{l}24 \\
(72.7 \%)\end{array}$ & $\begin{array}{l}7 \\
(21.2 \%)\end{array}$ & $\begin{array}{l}1 \\
(3 \%)\end{array}$ & - & $\begin{array}{l}1 \\
(3 \%)\end{array}$ \\
\hline $\begin{array}{l}\text { Through action research, I am now capable of } \\
\text { tackling some of the difficulties pupils in my class } \\
\text { encounter. }\end{array}$ & $\begin{array}{l}19 \\
(57.6 \%)\end{array}$ & $\begin{array}{l}13 \\
(39.4 \%)\end{array}$ & - & - & $\begin{array}{l}1 \\
(3 \%)\end{array}$ \\
\hline
\end{tabular}

19 | This work is licensed under a Creative Commons Attribution 4.0 International License. 
East African Journal of Education Studies, Volume 5, Issue 1, 2022

Article DOI: https://doi.org/10.37284/eajes.5.1.528

\begin{tabular}{|c|c|c|c|c|c|}
\hline Items & $\mathbf{S A}$ & $\mathbf{A}$ & D & SD & NR \\
\hline $\begin{array}{l}\text { By doing action research, I have learned where to } \\
\text { obtain information/literature to understand the } \\
\text { difficulties pupils in my class encounter. }\end{array}$ & $\begin{array}{l}21 \\
(63.60 \%)\end{array}$ & $\begin{array}{l}11 \\
(33 \%)\end{array}$ & - & - & $\begin{array}{l}1 \\
(3 \%)\end{array}$ \\
\hline $\begin{array}{l}\text { Doing action research has made me become more } \\
\text { confident to search for information from the } \\
\text { web/internet independently. }\end{array}$ & $\begin{array}{l}22 \\
(66.7 \%)\end{array}$ & $\begin{array}{l}10 \\
(30.3 \%)\end{array}$ & - & - & $\begin{array}{l}1 \\
(3 \%)\end{array}$ \\
\hline $\begin{array}{l}\text { I now understand the different strategies, methods, } \\
\text { and procedures to intervene when pupils in my class } \\
\text { are encountering difficulties. }\end{array}$ & $\begin{array}{l}17 \\
(51.5 \%)\end{array}$ & $\begin{array}{l}15 \\
(45.5 \%)\end{array}$ & - & - & $\begin{array}{l}1 \\
(3 \%)\end{array}$ \\
\hline $\begin{array}{l}\text { I can now use my laptop to design assessment tools } \\
\text { such as tests, rating scales, checklists, and anecdotal } \\
\text { records for my class. }\end{array}$ & $\begin{array}{l}17 \\
(51.5 \%)\end{array}$ & $\begin{array}{l}14 \\
(42.4 \%)\end{array}$ & $\begin{array}{l}1 \\
(3 \%)\end{array}$ & - & $\begin{array}{l}1 \\
(3 \%)\end{array}$ \\
\hline $\begin{array}{l}\text { My ability to organise/present ideas in a coherent } \\
\text { manner has improved through action research. }\end{array}$ & $\begin{array}{l}15 \\
(45.5 \%)\end{array}$ & $\begin{array}{l}17 \\
(51.5 \%)\end{array}$ & - & - & $\begin{array}{l}1 \\
(3 \%)\end{array}$ \\
\hline $\begin{array}{l}\text { I am now in a position to sensitise colleagues at my } \\
\text { school on the need for action research. }\end{array}$ & $\begin{array}{l}13 \\
(39.4 \%) \\
\end{array}$ & $\begin{array}{l}18 \\
(54.5 \%) \\
\end{array}$ & - & - & $\begin{array}{l}2 \\
(6.1 \%) \\
\end{array}$ \\
\hline $\begin{array}{l}\text { I can now work collaboratively with other teachers } \\
\text { at my school to identify problems and conduct } \\
\text { action research to find the solution. }\end{array}$ & $\begin{array}{l}14 \\
(42.4 \%)\end{array}$ & $\begin{array}{l}18 \\
(54.5 \%)\end{array}$ & - & - & 1 \\
\hline $\begin{array}{l}\text { I can now lead an action research team at my school } \\
\text { if I am called upon to take on the responsibility. }\end{array}$ & $\begin{array}{l}9 \\
(27.3 \%) \\
\end{array}$ & $\begin{array}{l}18 \\
(54.5 \%)\end{array}$ & $\begin{array}{l}3 \\
(9.1 \%)\end{array}$ & - & $\begin{array}{l}3 \\
(9.1 \%) \\
\end{array}$ \\
\hline Category Majority & 6 & 4 & 0 & 0 & 0 \\
\hline
\end{tabular}

$S A=$ Strongly Agree $; A=$ Agree $; D=$ Disagree $; S D=$ Strongly Disagree $; N R=$ non-response

Table 3 shows that the majority of the participants agreed that doing action research enabled them to develop a range of skills required to do action.

Table 4: The pattern of responses pertaining to difficulties in doing action research

\begin{tabular}{|c|c|c|c|c|}
\hline Items & High & Medium & Low & $\begin{array}{l}\text { Non- } \\
\text { Response }\end{array}$ \\
\hline Identifying a researchable problem & $6(18.2 \%)$ & $15(45.5 \%)$ & $12(36.4 \%)$ & - \\
\hline Formulating a research title. & $10(30.3 \%)$ & $16(48.5 \%)$ & $7(21.2 \%)$ & - \\
\hline $\begin{array}{l}\text { Reviewing literature/references } \\
\text { understand the problem. }\end{array}$ & $10(30.3 \%)$ & $18(54.5 \%)$ & $5(15.2 \%)$ & - \\
\hline Formulating research questions. & $7(21.2 \%)$ & $14(42.4 \%)$ & $11(33.3 \%)$ & $1(3 \%)$ \\
\hline $\begin{array}{l}\text { Choosing a suitable intervention strategy } \\
\text { to solve the problem that I have identified. }\end{array}$ & $6(18.2 \%)$ & $15(45.5 \%)$ & $11(33.3 \%)$ & $1(3 \%)$ \\
\hline $\begin{array}{l}\text { Choosing appropriate research design, } \\
\text { strategies, and methods. }\end{array}$ & $5(15.2 \%)$ & $20(60.6 \%)$ & $8(24.2 \%)$ & - \\
\hline Designing the tools for data collection. & $7(21.2 \%)$ & $13(39.4 \%)$ & $12(36.4 \%)$ & $1(3 \%)$ \\
\hline $\begin{array}{l}\text { Addressing ethical issues: permission, } \\
\text { informed } \\
\text { anonymity }\end{array}$ & $2(6.1 \%)$ & $14(42.4 \%)$ & $17(51.5 \%)$ & - \\
\hline $\begin{array}{l}\text { Implementing the intervention strategy and } \\
\text { collecting data. }\end{array}$ & $3(9.10 \%)$ & $18(54.5 \%)$ & $10(30.3 \%)$ & $2(6.1 \%)$ \\
\hline Organising and analysing collected data. & $4(12.1 \%)$ & $17(51.5 \%)$ & $11(33.3 \%)$ & $1(3 \%)$ \\
\hline Presenting the results. & $3(9.1 \%)$ & $21(63.6 \%)$ & $8(24.2 \%)$ & $1(3 \%)$ \\
\hline Producing a coherent report. & $7(21.2 \%)$ & $18(54.5 \%)$ & $7(21.2 \%)$ & $1(3 \%)$ \\
\hline
\end{tabular}

20 | This work is licensed under a Creative Commons Attribution 4.0 International License. 
East African Journal of Education Studies, Volume 5, Issue 1, 2022

Article DOI: https://doi.org/10.37284/eajes.5.1.528

\begin{tabular}{llllll}
\hline Items & High & Medium & Low & $\begin{array}{l}\text { Non- } \\
\text { Response }\end{array}$ \\
\hline $\begin{array}{l}\text { Compiling the list of references as } \\
\text { required. }\end{array}$ & $1(3 \%)$ & $20(60.6 \%)$ & $11(33.3 \%)$ & $1(3 \%)$ \\
\hline Writing the research proposal. & $8(24.2 \%)$ & $16(48.5 \%)$ & $9(27.3 \%)$ & - \\
\hline Writing the abstract. & $5(15.2 \%)$ & $12(36.4 \%)$ & $16(48.5 \%)$ & - \\
\hline Category Majority & 0 & 13 & 2 & 0 \\
\hline
\end{tabular}

Table 4 shows that among the fifteen items used to elicit responses on the difficulties in doing action research, the majority of the participants described thirteen as 'Medium' and two as Low. None was categorised as High.

Table 5: The pattern of opinion regarding the challenges in doing action research

\begin{tabular}{lllll}
\hline Items & High & Medium & Low & Non-Response \\
\hline The heavy workload at school. & $27(81.8 \%)$ & $6(18.2 \%)$ & - & - \\
\hline Family demands/pressure. & $14(42.4 \%)$ & $14(42.4 \%)$ & $4(12.1 \%)$ & $1(3 \%)$ \\
\hline $\begin{array}{l}\text { Too many courses, lectures, and } \\
\text { assignments to attend at SITE. }\end{array}$ & $10(30.3 \%)$ & $17(51.5 \%)$ & $5(15.2 \%)$ & $1(3 \%)$ \\
$\begin{array}{l}\text { The uncooperative attitude of head- } \\
\text { teacher/colleagues. }\end{array}$ & $7(21.2 \%)$ & $8(24.2 \%)$ & $17(51.5 \%)$ & $1(3 \%)$ \\
\hline $\begin{array}{l}\text { Inability to settle down and focus on the } \\
\text { research. }\end{array}$ & $3(9.1 \%)$ & $17(51.5 \%)$ & $12(36.4 \%)$ & $1(3 \%)$ \\
\hline Not having sufficient ICT skills. & $2(6.1 \%)$ & $12(36.4 \%)$ & $19(57.6 \%)$ & - \\
\hline $\begin{array}{l}\text { Lack of regular access to the } \\
\text { internet/network. }\end{array}$ & $5(15.2 \%)$ & $11(33.3 \%)$ & $16(48.5 \%)$ & $1(3 \%)$ \\
\hline $\begin{array}{l}\text { Not having a personal computer/laptop } \\
\text { to work with. }\end{array}$ & $3(9.1 \%)$ & $5(15.2 \%)$ & $24(72.7 \%)$ & $1(3 \%)$ \\
\hline $\begin{array}{l}\text { Library not equipped with relevant } \\
\text { books, journals, etc. }\end{array}$ & $12(36.4 \%)$ & $4(12.10 \%)$ & $16(48.5 \%)$ & $1(3 \%)$ \\
\hline $\begin{array}{l}\text { Lecturer/supervisor not supportive. } \\
\text { Category Majority }\end{array}$ & $2(3 \%)$ & $1(3 \%)$ & $31(93.9 \%)$ & $1(3 \%)$ \\
\hline
\end{tabular}

Table 5 shows that among the ten challenges in doing action research that is listed, the majority of the participants described six as Low, 2 Medium, and 2 High. The two highs are heavy workload at school and family demands/pressure.

\section{DISCUSSION}

This study explores the experience of a sample of teachers from Seychelles regarding action research concentrating on their background characteristics, their understanding of the nature, meaning, and purpose of action research; the benefits they gained from doing action research; and the difficulties and challenges they encountered with a view to identifying their successes, concerns, and issues. It can be seen from Table 2 that the majority were successful when their understanding of the meaning, nature, and purpose of action research was assessed using a set of questions for which they provided written responses. Eighty-two percent of the sample were able to define the term 'Research' using appropriate phrases while $12 \%$ were unable (see Table 2) when the definitions they gave were evaluated against Asenahabi (2019, p. 77) who defines research as a careful and systematic way of solving problems and gaining new knowledge. Those who were unable to give the correct definition of research possibly did understand the nature of the scientific method discussed during coursework. This inference is also shared by Bahçekapili et al. (2013) who note that individuals who could not provide a technical definition of research do not understand that research usually begins with a problem and culminates in a solution to it.

21 This work is licensed under a Creative Commons Attribution 4.0 International License. 
When asked why it is important to research into a problem before seeking a solution to it, the majority (76\% of the sample) gave correct answers and 12\% were incorrect when their answers were weighed against Carson (2007), emphasised that it is advisable to research into a problem first so as to become aware of it and determine what it is or what is required to find a solution to it. The majority (82\%) gave appropriate answers using correct phrases and $18 \%$ were unable when asked to define 'Action Research. Their responses were evaluated against Khasinah (2013, p. 108) who defines action research as a type of inquiry carried out by practitioners with a view to improving their professional practice and understanding it better. All 33 participants agree with Mettetal (2001, p. 1) that classroom teachers should be able to conduct action research because they are in a better position than anyone else to find out what works best in their own classroom. The majority were able to answer these questions correctly owing to the fact that they had completed their action research assignment prior to the survey. Hence, their responses were mostly from experience. It can be inferred that the few who lagged behind did not understand the meaning and nature of action research when they were discussed during coursework or they were unable to relate they have learned to practice.

The pattern of their responses regarding the benefits of doing action research was skewed. Most of their responses for the ten items clustering around Strongly Agree and Agreed categories, an indication that the majority of the participants benefitted from doing action research by developing a range of skills required to conduct classroombased research, including 'increased awareness of the needs of their pupils; work collaboratively with other teachers to identify problems and conduct action research to find a solution; and, the willingness to lead an action research team in their school'. This result supports researchers (see Hine \& Lavery, 2014; Riel, 2019: Vula \& Saqipi, 2015, Ulla, 2018) who also found that action research nurtures the technical skills and specialised knowledge teachers require to improve their teaching practice and enhance pupils' achievement. When they were asked to indicate the difficulties encountered by their learners, the majority identified Reading' and 'Comprehension (see Table 1). Given that the participants came from schools across Mahe (the main island), one may argue that inability of the pupils to read and comprehend what they are reading is a common problem in state primary schools in Seychelles. It is also likely most of the participants might choose to explore difficulties relating to reading and comprehension in their action research assignment.

Most of the participants described the difficulties they encountered as 'Medium'. A closer analysis of the results shows the difficulties have to do with research methodology. Hence, it can be inferred they did not find research methodology daunting even though most of them had no experience of action research prior to their in-service training and their institutions did not emphasise action research as a teacher development strategy. However, there were a few who found research methodology highly difficult despite that the course was offered to the entire class and they did their project under the supervision of their lecturer. Three percent of the sample (one participant) reported inadequate support from the lecturer/supervisor. These observations support some previous research (see Ulla, 2018; Morales et al., 2016; Nagibova, 2016; Norasmah \& Chiah, 2016), who also found that teachers find research methodology daunting.

They also encountered a number of challenges, but only two (namely heavy workload at school and family demands) were described by the majority as High (see Table 5). The fact that they described most of the challenges faced as Low implies they were not overwhelmed, despite that they had no experience of action research prior to their inservice training. This success could be a function of their maturity - all were above 30 years of age, had more than 10 years of teaching experience, and in the Upper Primary as shown in Table 1. Following Leila and Morteza's (2015) model for categorising the challenges in doing action research, the two identified Highs are individual/personal challenges. This observation validates previous research studies (see Norasmah \& Chiah, 2016; Ulla, 2018). According to Millar (2016:10), research is the most intimidating of all academic tasks; therefore, the action research project that the participants did may have tested their dodginess and resilience.

For the most part, the participants demonstrated the competencies needed to undertake action research. 
One might infer that the training they received did develop them professionally. Given that there were about 800 primary school teachers in the country, these teachers $(\mathrm{N}=33)$ constituted a small proportion of the population. Since they came from various schools across the country and were experienced teachers (See Table 1), they can now serve as change champions to promote a culture of collaborative problem-solving in their schools while effort should be made to address their concerns. As Petit, 2010) emphasised, action research provides an alternative approach to bringing about changes in knowledge, policy, and practice. Given that action research was not emphasised in their institution (see Table 1) and they now understand the purpose of action research (see Table 2) and are poised to lead the action research team (see Table 3), they can initiate conversations that might inspire their management to incorporate action research into their strategic plan. Following that few management positions (see Table 1) and some of them might be promoted to such positions now that they have completed advanced training, they may begin to consider incorporating action research into teacher performance evaluation so that their teachers will begin to see action research as part of their roles as professionals. They may also see the need to introduce platforms for teachers to share perspectives, such as seminars and conferences. These measures may help to mitigate some of the difficulties the teachers encountered in doing action research.

\section{CONCLUSION}

Looking back, the purpose of this research was to provide a descriptive account of the experience of a sample of teachers from Seychelles regarding action research aimed to identify their accomplishments, difficulties, and challenges. The sample $(\mathrm{N}=33$ primary school teachers on in-service training at a teacher education institution) individually completed action research as a component of their assessment task on the Introduction to Educational Research course. Following the results presented and the discussions, most of the teachers understood the nature, meaning, and purpose of action research. They acquired the competencies needed to conduct action research. Even though they encountered some difficulties and challenges while doing their action research project, they were not overwhelmed.
It can be inferred from the findings that they have developed the capacity to explore and find solutions to the problems they and their pupils encounter in their classroom and school rather than expecting outsiders to salvage them. However, a few fell short of expectations in some areas, despite receiving the same training and support as their successful classmates. They will need to work in teams with their successful colleagues to catch up. In addition, the training institution should take note of the major concerns and issues raised by the participants of this survey and take necessary measures to ensure that future cohorts will not encounter the same. Given that none of the previous studies that investigated teachers' experience regarding action research involved samples from Seychelles, a small island state in the Indian Ocean region, this study did and has closed some empirical gaps left by previous research. However, the findings cannot be generalised to the wider context owing to the sampling design employed. Given that the participants were in-service teachers, future research involving full-serving teachers is recommended.

\section{ACKNOWLEDGEMENT}

The authors are grateful to the Principal Secretary in the Ministry of Education Seychelles, Dr. Odile de Comarmond, for granting approval to involve the teachers in this survey and to the teachers for accepting to participate in it.

\section{REFERENCES}

Asenahabi, B. M. (2019). Constraints Encountered by Secondary Schools in offering Computer Studies. International Journal of Contemporary Applied Researches, 6(5), 159-174.

Bahçekapili, E., Bahçekapili, T., Fiş Erümit, S.; Göktaş, Y. \& Sözbilir, M. (2013). The Factors Affecting Definition of Research Problems in Educational Technology Research. Educational Sciences: Theory \& Practice, 13(4), 2330-2335.

Cabaroglu, N. (2014). Professional development through action research: Impact on self-efficacy. System, 44 (1), 79-88.

Carson, J. (2007). A Problem with Problem Solving: Teaching Thinking Without Teaching 
Knowledge. The Mathematics Educator, 17(2), 7-14.

Daher, M., Carré, D., Jaramillo, A., Oilvares, H. \& Tmicic, A. (2017). Experience and Meaning in Qualitative Research: A Conceptual Review and a Methodological Device Proposal. Forum: Qualitative Social Research, 18(3), Art. 9.

Darling-Hammond, L., Hyler, M. E. \& Gardner, M. (2017). Effective Teacher Professional Development. Palo Alto, CA: Learning Policy Institute. In: https://learningpolicyinstitute.org/s ites/default/files/product- files/Effective_Teach er_Professional_Development_REPORT.pdf.

Depraz, N., Varela, F. J., \& Vermersch, P. (2003). On Becoming Aware: A Pragmatics of Experiencing. Amsterdam: John Benjamins Publishing.

Economic Commission for Africa (2018), Country Profile 2017: Seychelles. Addis Ababa, Ethiopia. Economic Commission for Africa. In: http://www.uneca.org/sites/default/files/uploade ddouments/CountryProfiles/2018/Seychelles_cp _2017_en.pdf

Hine, G. S. C. (2013). The importance of action research in teacher education programs. Issues in Educational Research, 23(2), Special Issue, 151163.

Khan, R. Grijalva, R. \& Enriquez-Gates, A. (2019). Teachers as Change Agents: Promoting Meaningful Professional Development Using Action Research to Support International Educational Reform. Forum for International Research in Education, 5(2), 214-225.

Khasinah, S. (2013). Classroom Action Research. PIONIR Jurnal Pendidikan, 4: 107-14. In: https://core.ac.uk/download/pdf/228447953.pdf

Leila, H. \& Morteza, H. A. (2015). Study of the Obstacles to Conducting the Action Research from the Primary School Teachers' Point of View in Bijar. International Journal of Academic Research in Progressive Education and Development, 4 (1), 169-177.
Malhotra, G. (2017). Strategies in Research. International Journal of Advance Research and Development, 2(5), 172-180.

Martin-Kniep, G. O. (2000). Becoming a Better Teacher: Eight innovations that work. Alexandria, Virginia: Association for Supervision and Curriculum Development.

Mettetal, G. (2001). The What, Why and How of Classroom Action Research. In: https://www.researchgate.net/publication/24217 9106_The_What_Why_and_How_of_Classroo m_Action_Research/link/55b2758408aec0e5f4 $31 \mathrm{~cd} 4 \mathrm{c} /$ download.

Millar, C. (2016). A Practical Guide to Classroom Research. Northwich: Critical Publishers.

Ministry of Education (2019). Schools. Mont Fleuri, Seychelles: Ministry of Education. In: www.education.gov.sc/pages/school/aspx.

Morales, M. P. E., Abulon, E. L. R., Soriano, P. R., Ma, A. P. D., Hermosisima, V. C. \& Gerundio, M. G. (2016). Examining teachers' conception of and needs on action research. Issues in Educational Research, 26 (3), 464-489.

Nagibova, G. (2016). Professional Development: The Challenges of Action Research Implementation in Kazakhstan. International Academy Web of Scholar, 9(39), 2, 17-24.

Norasmah, O. \& Chiah, S. Y. (2016). The Challenges of Action Research Implementation in Malaysian Schools. Pertanika Journal of Social Science \& Humanities, 24(1): 43-52.

Orgoványi-Gajdos, S. (2016). Teachers' Professional Development on Problem Solving: Theory and Practice for Teachers and Teacher Educators. Rotterdam, Netherlands: Sense Publishers.

Petit, J. (2010). Learning to do Action Research for Social Change. International Journal of Communication, 4 (2010), Feature 820-827.

Riel, M. (2019). Understanding Collaborative Action Research. Inquiry in Education, 1(1), Art.1. 
Roth, W. \& Jornet, A. (2014). Towards A Theory of Experience. Science Education, 98(1), 106-126.

Rubio, C. M. (2010). Effective Teachers Professional and Personal Skills. ENSAYOS, Revista de la Facultad de Educación de Albacete, $\mathrm{N}^{\mathrm{o}} \quad 24, \quad 2009 . \quad$ Available at: https://dialnet.unirioja.es/descarga/articulo/3282 843.pdf Accessed 22/11/2021.

Shanks, J. (2016). Implementing Action Research and Professional Learning Communities in a Professional Development School Setting to Support Teacher Candidate Learning. SchoolUniversity Partnerships, 9(1), 45-53.

Srinivasacharlu, A. (2019). Continuing Professional Development (CPD) of Teacher Educators in 21st Century. International Journal of Education, 7(4), 29-33.

Tertiary Education Seychelles (2020). Tertiary Education Institutions. In: https://www.tec.sc/te rtiary-education-institutions.

Ulla, M. B. (2018). Benefits and challenges of doing research: Experiences from Philippine publicschool teachers. Issues in Educational Research, 28(3), 797-810.

UNESCO Institute of Statistics (2021). Basic Research. In: http://uis.unesco.org/en/glossaryterm/basic-research

Vula, E. \& Saqipi, B. (2015). Developing Action Research for Developing Teachers in Kosovo. Turkish Online Journal of Qualitative Inquiry (TOJQI), 6(4), 1-21. 